\title{
Performance Evaluation of the ARCHITECT HE4
} Assay

Eun-Jung Cho, DaeHyun Ko, Tae-Dong Jeong, Woochang Lee, Sail Chun, and Won-Ki Min

Department of Laboratory

Medicine, Asan Medical

Center, University of Ulsan College of Medicine, Seoul, Korea

\section{Corresponding author:} Woochang Lee

Department of Laboratory Medicine, Asan Medical Center, University of Ulsan College of Medicine, 88 Olympic-ro 43-gil, Songpa-gu, Seoul 138-736, Korea Tel: $+82-2-3010-4506$

Fax: +82-2-478-0884

E-mail: wlee1@amc.seoul.kr

pISSN: $1225-097 \mathrm{X}$

elSSN: 2288-7261
Background: Human epididymis protein 4 (HE4) is known to be overexpressed in ovarian cancer, and therefore, it can be considered an important biomarker of epithelial ovarian cancer. HE4 shows higher specificity than cancer antigen 125 (CA-125); this characteristic can be used to discriminate between benign and malignant pelvic masses. The Risk of Ovarian Malignancy Algorithm (ROMA) value based on the results obtained for CA-125 and HE4 is used for risk assessment for ovarian cancer. The aim of this study is to evaluate the performance of ARCHITECT HE4 assay (Abbott Laboratories, US) and ROMA value.

Methods: Precision, linearity, limit of blank (LoB), and limit of detection (LoD) values were evaluated on the basis of the guidelines supplied by the Clinical and Laboratory Standards Institute. All assay procedures were performed on an Architect i2000 analyzer (Abbott Laboratories, US) using the ARCHITECT HE4 assay reagent. ARCHITECT HE4 quality control materials, calibrator $\mathrm{B}$, calibrator $\mathrm{F}$, multi assay diluent, and patient serum samples were used for the assay. ROMA values (\%) were calculated for patients and healthy controls based on their menopausal state.

Results: A total CV of 3\% was noted for precision analysis. Linearity was confirmed in the analytic measurement range (AMR). LoB and LoD values were below the lower limit of AMR. The ROMA values for patients with ovarian cancer were higher than those for healthy controls.

Conclusions: The ARCHITECT HE4 assay showed suitable analytical performance characteristics with respect to precision, linearity, LoB, and LoD. This assay, along with ROMA values, is expected to be widely used for rapid risk assessment and differential diagnosis of patients with pelvic mass.

(J Lab Med Qual Assur 2014;36:149-156)

Key Words : HE4, Ovarian neoplasms, Risk

Received August 15, 2014, Revision received September 2, 2014, Accepted September 10, 2014

\section{서론}

난소암은 부인암 중 자궁경부암 다음으로 주된 사망 원인이 되는 질환으로서 국내에서 암 사망률 연령표준화발생률(age standardized incidence rate)이 인구 100,000명당 6.1로 8번 째로 높은 빈도를 보인다[1]. 난소암은 조기에 발견하면 5년 생존률이 $90 \%$ 로 높으나, 난소암이 진행되어 발견되는 경우는 생존률이 $10 \%$ 미만으로 낮다[2]. 또한 난소암의 대부분이 진 행된 상태에서 발견되므로 예후가 나쁘다고 알려져 있다. 이는 난소암 초기에는 무증상인 경우가 대부분이고, 증상이 있더라
고 비특이적므로 양성질환과 감별이 어렵기 때문이다[3].

난소암의 감별진단에 초음파 진단과 함께 cancer antigen 125 (CA-125)를 이용하여 왔다[4]. 2008년 이전에는 CA125 가 난소암에서 유일하게 Food and Drug Administration (FDA) 승인 받은 종양표지자로서 골반종괴의 감별진단, 난소 암의 진단, 치료효과, 예후 판정과 재발 예측을 하는 지표로 사 용되어왔다[5]. 그러나 CA-125는 정상적인 자궁내막과 탈락 막(decidua)에서 생성되는 항원이며, 정상적인 난소 상피와 다른 장기에서도 분비될 수 있다[6]. CA-125가 생리적인 상 태, 양성질환과 난소암 모두에서 증가될 수 있고, 조기 난소암 


\title{
Journal of LABORATORY MEDICINE and QUALITY ASSURANCE
}

\author{
Eun-Jung Cho et al • Performance of ARCHITECT HE4 Assay
}

의 $50 \%$ 미만에서만 증가되므로 양성예측도와 특이도가 낮다 는 보고들이 있다[4,7].

최근에는 정상조직과 비교하여 난소암에서 과발현되는 유 전자인 WFDC2 (HE4) gene의 산물인 인간부고환단백 4 (human epididymis-specific protein 4, HE4)가 난소암의 종 양표지자로서 주목받고 있다. 특히 상피성 난소암에서 과발현 되며, 조직학적 유형에 따라 분비되는 정도에 차이를 보이지 만, 발생빈도가 가장 높은 장액성 난소암(serous carcinoma) 의 $93 \%$, 자궁내막양 난소암(endometrioid carcinoma)의 $100 \%$ 에서 분비된다고 알려져 있다. 점액성 난소암(mucinous carcinoma)과 투명세포암(clear cell carcinoma)에서 는 제한적으로 분비된다고 알려져 있다[8]. 본 연구에서는 ARCHITECT HE4 assay를 대상으로 정밀도(precision), 직 선성(linearity), 검출한계(detection limit) 등의 수행능을 평 가하고자 하였다.

$\mathrm{HE} 4$ 는 $\mathrm{CA}-125$ 보다 양성과 악성의 골반종괴를 감별하는 데 있어서 진단적 특이도가 높으며, CA- 125 와 HE4를 동시에 측정하면 특히 난소상피암 위험군 선별검사로서의 민감도가 더 높아진다고 제시한 연구가 있었다[9]. 최근에는 골반종괴 를 가진 경우 $\mathrm{CA}-125$ 와 $\mathrm{HE} 4$ 의 검사결과를 기반으로 폐경 여 부에 따라 Risk of Ovarian Malignancy Algorithm (ROMA) value를 계산하여 난소암의 위험도를 예측하고 있다 $[9,10]$. 또한 ROMA value는 HE4를 단독으로 사용하는 것보다 민 감도와 특이도가 높다고 보고되고 있다 $[3,11]$. 본 연구에서는 $\mathrm{HE} 4$ 검사의 수행능 평가의 일부로서 정상인과 환자군에서의 ROMA value를 비교하였다.

\section{재료 및 방법}

\section{1. 대상}

검체는 2014년 7월부터 2014년 8월까지 CA-125 검사가 의 뢰되었던 산부인과 환자 16 명과 정상인 4 명의 잔여 혈청 검체 를 사용하였으며, 검사 시행 전까지 $-70^{\circ} \mathrm{C}$ 이하에서 냉동보관 하였다. 대상 환자의 의무기록을 후향적으로 검토하여 폐경 여 부, 과거력과 병리학적 소견 등을 분석하였다.

\section{2. 검사방법}

ARCHITECT i2000 immunoassay analyzer (Abbott Laboratories, Abbott Park, IL, USA) 장비를 사용하여 ARCHITECT HE4 assay (Abbott Laboratories, USA)와 ARCHITECT CA 125 II assay (Abbott Laboratories, USA) 시약을 사용하여 측정하였다. ARCHITECT HE4 assay와
ARCHITECT CA 125 II assay는 화학 발광 미세입자 면역분 석법(chemiluminescent microparticle immunoassay)을 원 리로 하고 있으며, 2단계의 샌드위치 면역측정법(sandwich immunoassay)에 의해 이루어진다. 1단계에서 capture항체 로서 anti-human HE4 antibody (mouse monoclonal, 2H5) 가 결합된 paramagnetic microparticles과 검체 내 항원 이 반응하며, 2단계에서는 검출항체로서 anti-HE4 (mouse monoclonal, 3D8) acridinium이 표지된 접합체를 첨가하면, 화학 발광반응에 의하여 발광신호가 방출되고 이를 측정하게 된다.

\section{3. 정밀도}

정밀도(precision) 평가는 Clinical and Laboratory Standards Institute (CLSI) EP5-A2 지침에 준하여 수행하 였다[12]. 사람 혈청 성분을 기질로 하는 ARCHITECT HE4 정도관리물질을 사용하였으며, 세 가지 농도의 정도관리물질 을 연속해서 20 일간 하루에 2 시간 이상의 간격을 두고 오전과 오후로 나누어 2회씩 측정하였고, 매 검사마다 두 번 반복 측 정하였다. 측정된 결과로 각 농도별 평균, 표준편차, 검사 내 변이계수(within-run CV)와 총 변이계수(total CV) 등을 계 산하였다.

\section{4. 직선성}

직선성 (linearity)은 CLSI EP6-A의 지침에 따라 calibrator $\mathrm{B}(30 \mathrm{pmol} / \mathrm{L})$ 를 2 배 희석한 물질과 calibrator F $(1,500$ $\mathrm{pmol} / \mathrm{L}$ )를 사용하여 평가하였다[13]. 제조사의 측정가능범위 (analytic measurement range, AMR: 20.0-1500.0 pmol/L) 를 고려하여 저농도에서 고농도까지 5 가지 농도로 계대 희석 하여 각각의 농도에 대해 4 회씩 반복 측정하였다. 농도별 측정 값의 평균을 기대값과 비교하였다.

\section{5. 검출한계}

검출한계(detection limit)는 CLSI EP17-A2 지침을 참고하 여 평가하였다[14]. Limit of blank (LoB)는 공백검체(blank sample)인 multi assay diluent $(0.0 \mathrm{pmol} / \mathrm{L})$ 를 이용하여 20 회 반복 측정한 relative light unit (RLU)값의 평균과 표준편 차를 제조사에서 제시하는 zero calibrator RLU의 허용범위 와 비교하였다. Limit of detection ( $\mathrm{LoD}$ ) 설정은 calibrator $\mathrm{B}(30 \mathrm{pmol} / \mathrm{L})$ 를 2 배 희석한 물질을 사용하였다.

\section{Risk of Ovarian Malignancy Algorithm}

$\mathrm{ROMA}(\%)$ 는 폐경 여부에 따라서 난소암의 위험도를 예 
측하는 알고리즘으로, $\mathrm{CA}-125$ 와 $\mathrm{HE} 4$ 측정값으로 predictive index $(\mathrm{PI})$ 를 수학적으로 계산한 것이다[3]. ROMA (\%)의 계 산식은 다음과 같으며, 장비에서 폐경 전과 후의 값 모두를 제 시해준다. 환자 16 명과 정상인 4 명을 대상으로 ROMA value 를 계산하였다. PI 계산식은 다음과 같다.

Premenopause PI $=-12.0+23.8 \times \operatorname{Ln}(\mathrm{HE} 4)+0.0626 \times$

$$
\text { Ln }(\mathrm{CA}-125)
$$

Postmenopause PI $=-8.09+1.04 \times \operatorname{Ln}(\mathrm{HE} 4)+0.732 \times \operatorname{Ln}$

$$
(\mathrm{CA}-125)
$$

계산된 $\mathrm{PI}$ 값으로 다음과 같은 식에 의하여 $\mathrm{ROMA}(\%)$ 를 구한다.

Predicted probability $=\exp (\mathrm{PI}) /[1+\exp (\mathrm{PI})]$

ROMA $(\%)=\exp (\mathrm{PI}) /[1+\exp (\mathrm{PI})] \times 100$

\section{7. 통계분석}

통계분석에는 EP Evaluator Release 10 (David G. Rhoads Assoc., Kennett Square, PA, USA), SPSS ver.
13.0 (SPSS Inc., Chicago, IL, USA)과 Microsoft office Excel 2007 (Microsoft Co., Redmond, WA, USA) 소프트웨 어를 이용하였다.

\section{결과}

\section{1. 정밀도}

검사항목별 평균, 표준편차, 검사 내 변이계수, 총 변이계 수는 Table 1 과 같다. 검사 내 정밀도의 변이계수는 level 1은 $2.0 \%$, level 2 는 $1.9 \%$, level 3 는 $0.5 \%$, 총 변이계수는 세 가 지 농도에서 각각 $2.3 \%, 2.4 \%, 1.1 \%$ 로 각 세 농도 모두에서 총 변이계수는 $3 \%$ 미만의 결과를 보였다.

\section{2. 직선성}

참고범위를 포함한 제조사의 측정가능범위인 20.0-1,500.0 $\mathrm{pmol} / \mathrm{L}$ 의 농도구간에서 직선성을 만족하였다(Fig. 1).

\begin{tabular}{|c|c|c|c|c|c|}
\hline \multirow{2}{*}{ Analyte (units) } & \multirow{2}{*}{ Level } & \multirow{2}{*}{ Mean } & \multirow{2}{*}{$\mathrm{SD}$} & \multicolumn{2}{|c|}{ CV (\%) } \\
\hline & & & & Within-run & Total \\
\hline \multicolumn{6}{|l|}{ HE4 (pmol/L) } \\
\hline & Low & 50.13 & 0.98 & 2.0 & 2.3 \\
\hline & Middle & 172.18 & 3.30 & 1.9 & 2.4 \\
\hline & High & 678.90 & 3.71 & 0.5 & 1.1 \\
\hline
\end{tabular}

Table 1. Precision profile of ARCHITECT HE4 assay

Abbreviation: HE4, human epididymis protein 4.

A

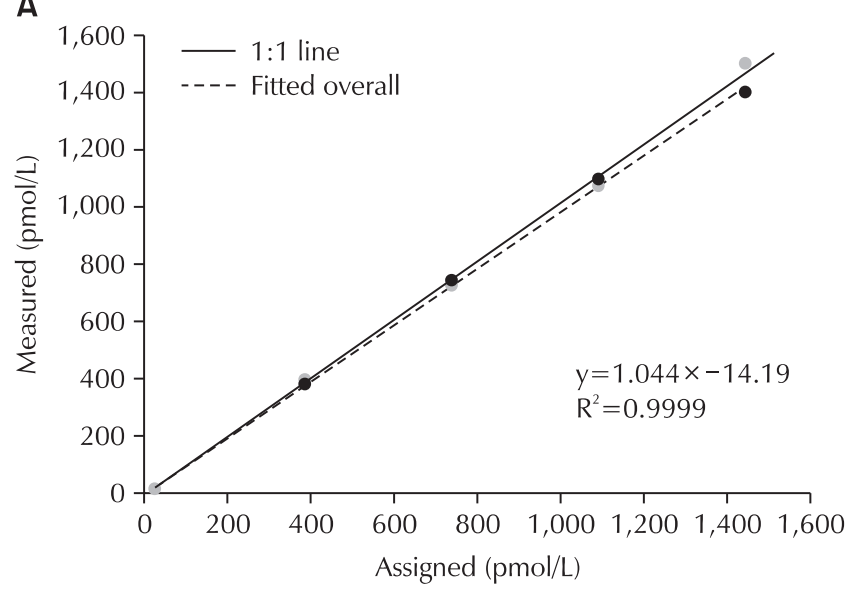

B

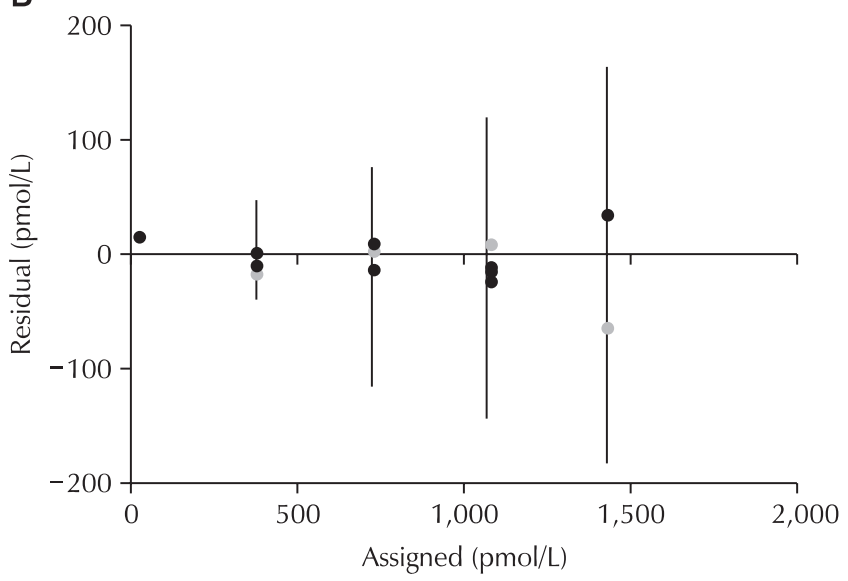

Fig. 1. (A) Linearity of ARCHITECT HE4 assay, as estimated by Architect i2000 analyzer Scatter plot and (B) residual plot are shown. 


\section{3. 검출한계}

공백검체의 측정값 평균은 185.1 RLU로 제조사가 제시한 농도 $0 \mathrm{pmol} / \mathrm{L}$ 인 calibrator의 기대되는 134-755 RLU의 범 위에 속했으며(data not shown), calibrator B를 2배 희석하 여 $\mathrm{LoD}$ 검증에 사용한 물질의 평균 농도는 $14.7 \mathrm{pmol} / \mathrm{L}$ 이었 다. $\mathrm{LoD}$ 값은 제조사가 제시한 정량한계인 $20 \mathrm{pmol} / \mathrm{L}$ 보다 낮 았다.

\section{Risk of Ovarian Malignancy Algorithm}

제조사가 제시하는 $\mathrm{HE} 4$ 측정값의 참고치는 폐경 전 여성 이 $70 \mathrm{pmol} / \mathrm{L}$ 이하, 폐경 후 여성이 $140 \mathrm{pmol} / \mathrm{L}$ 이하이다. 또 한 ROMA value는 폐경 전 환자에서 ROMA value가 $7.4 \%$ 이상, 폐경 후 환자에서는 $25.3 \%$ 이상인 경우를 난소암의 가 능성이 높은 것으로 판정한다. $\mathrm{CA}-125$ 와 $\mathrm{HE} 4$ 값을 이용한 $\mathrm{ROMA}(\%)$ 는 Table 2 에 제시되어 있다. 난소암 환자군 16
명 중 2명(12.5\%)은 CA-125 수치가 CA-125 cutoff인 $35 \mathrm{U} /$ $\mathrm{mL}$ 이하였으며, HE4 수치가 폐경 후 여성의 HE4 cutoff인 $140 \mathrm{pmol} / \mathrm{L}$ 이하인 경우는 8명(50.0\%)이었다. HE4 수치가 정상을 보인 환자군 중 6 명의 ROMA value는 폐경 후 환자 의 ROMA value cutoff인 $25.3 \%$ 보다 컸다. 16 명의 환자군 중 2명에서만 ROMA value가 $25.3 \%$ 미만으로 정상범위에 속 했다. 측정범위 상한값을 벗어난 2명 (patient no. 11 and no. 12)의 환자결과는 $1: 10$ 으로 희석하여 정량값을 구하였다.

\section{고찰}

난소암은 조기에 발견하면 생존률이 양호한 암종으로서 조 기진단의 중요성이 강조되고 있다[15]. 과거부터 CA- 125 를 난소암의 선별검사와 치료반응과 예후 평가에 이용하여 왔으 나, 양성질환에서 증가될 수 있고, 재발하는 경우에도 난소암

Table 2. HE4, CA-125, and ROMA values in healthy controls and patients with ovarian cancer

\begin{tabular}{|c|c|c|c|c|c|c|}
\hline $\begin{array}{l}\text { Patient } \\
\text { no. }\end{array}$ & Clinical status & $\begin{array}{l}\text { Menstrual } \\
\text { status }\end{array}$ & $\begin{array}{l}\text { CA-125 } \\
(\mathrm{U} / \mathrm{mL})\end{array}$ & $\begin{array}{c}\text { HE4 } \\
(\mathrm{pmol} / \mathrm{L})\end{array}$ & $\begin{array}{l}\text { PreM ROMA } \\
(\%)\end{array}$ & $\begin{array}{l}\text { PostM ROMA } \\
(\%)\end{array}$ \\
\hline 1 & Healthy & PreM & 9.1 & 27.2 & 1.8 & 4.6 \\
\hline 2 & Healthy & PreM & 24.2 & 36.4 & 3.7 & 11.7 \\
\hline 3 & Healthy & PreM & 20.1 & 48.6 & 7.1 & 13.5 \\
\hline 4 & Healthy & PreM & 11.7 & 30.2 & 2.3 & 6.0 \\
\hline 5 & Serous carcinoma & PostM & 12.3 & 44.9 & 5.8 & 9.2 \\
\hline 6 & Serous carcinoma & PostM & 340.1 & 64.2 & 15.1 & 62.4 \\
\hline 7 & Serous carcinoma & PostM & 785.1 & 718.1 & 98.3 & 97.4 \\
\hline 8 & $\begin{array}{l}\text { Mixed epithelial carcinoma (serous carcinoma } \\
70 \% \text { and clear cell carcinoma 30\%) }\end{array}$ & PostM & 92.3 & 71.1 & 17.2 & 41.5 \\
\hline 9 & Serous carcinoma & PostM & 1288.2 & 956.0 & 99.2 & 98.6 \\
\hline 10 & Serous carcinoma & PostM & 407.9 & 1366.6 & 99.6 & 97.9 \\
\hline 11 & Serous carcinoma & PostM & 3984.9 & 4752.8 & 100.0 & 99.9 \\
\hline 12 & Serous carcinoma & PostM & 892.7 & 3907.7 & 100.0 & 99.6 \\
\hline 13 & Serous carcinoma & PostM & 11.4 & 42.0 & 5.0 & 8.2 \\
\hline 14 & Serous carcinoma & PostM & 720.0 & 196.4 & 72.7 & 90.2 \\
\hline 15 & Serous carcinoma & PostM & 144.6 & 34.3 & 3.6 & 31.6 \\
\hline 16 & Serous carcinoma & PostM & 114.6 & 204.7 & 72.3 & 71.4 \\
\hline 17 & $\begin{array}{l}\text { Mixed carcinoma (serous carcinoma } 80 \% \text { and } \\
\text { endometrioid carcinoma } 20 \% \text { ) }\end{array}$ & PostM & 68.2 & 76.6 & 19.6 & 38.1 \\
\hline 18 & Serous carcinoma & PostM & 238.5 & 1038.3 & 99.2 & 95.9 \\
\hline 19 & Clear cell carcinoma & PostM & 142.9 & 41.6 & 5.6 & 35.9 \\
\hline 20 & Clear cell carcinoma & PostM & 210.7 & 45.9 & 7.2 & 45.2 \\
\hline
\end{tabular}

Cutoff value: CA-125, $35 \mathrm{U} / \mathrm{mL}$; HE4, preM $70 \mathrm{pmol} / \mathrm{L}$ and postM $140 \mathrm{pmol} / \mathrm{L}$; ROMA, preM 7.4\% and postM 25.3\%.

Abbreviations: HE4, human epididymis protein 4; CA-125, cancer antigen 125; PreM, premenopause; PostM, postmenopause; ROMA, Risk of Ovarian Malignancy Algorithm. 


\title{
Journal of LABORATORY MEDICINE and QUALITY ASSURANCE
}

\author{
Eun-Jung Cho et al • Performance of ARCHITECT HE4 Assay
}

의 $25 \%$ 에서만 증가하므로 민감도가 낮다고 보고되어 왔다 〔15,16]. 2003년 HE4가 정상조직에 비하여 난소암에 상대적 으로 과발현되어 분비된다는 것이 밝혀지면서 새로운 난소암 의 종양표지자로서의 가능성이 제시되어 왔다[17]. 또한 양 성질환에서는 CA-125보다 증가되는 빈도가 낮으므로 수술 전 골반종괴의 악성 여부를 판단하는 지표로 이용되어 왔다 $\lceil 18,19]$. 그리고 Moore 등[9]은 CA-125와 HE4의 결과값을 통하여 난소암의 위험도를 예측하는 ROMA 알고리즘을 제시 하였다. 난소암의 진단에서 $\mathrm{CA}-125$ 단독 검사보다 $\mathrm{HE} 4$ 를 단 독으로 검사하였을 경우 진단적 특이도가 높고, ROMA value 의 경우 민감도와 특이도가 더 우수하다는 이전 연구들이 있다 $\lceil 3,20]$. 본 연구는 $\mathrm{HE} 4$ 를 측정하여 $\mathrm{CA}-125$ 결과를 종합하여 ROMA value를 산출하는 ARCHITECT HE4 assay의 수행 능을 평가하였다.

정밀도 평가결과 모든 농도에서 총 변이계수는 $3 \%$ 미만 이었다. HE4에 대해서는 CLSI 또는 Clinical Laboratory Improvement Amendments of 1988에서 제시하는 정밀 도 허용기준이 없다. 그러나 National Academy of Clinical Biochemistry (NACB)에서는 종양표지자 검사의 정밀도 허 용기준으로 검사 중 변이계수 5\% 미만, 총 변이계수는 $20 \%$ 미만을 권장하고 있다[21]. 조직에서 분비되는 물질의 경우 개 인 내 또는 개인간 생물학적 변이가 높을 것이라는 이전 연구 결과도 있지만[22], HE4가 난소의 기능이나 호르몬의 영향을 받지 않고 난소 종양에서 분비되는 특성으로 상대적으로 일정 하게 유지된다는 상반된 연구결과도 있다[23]. 정밀도 평가의 다양한 판단기준이 존재하지만, $\mathrm{NACB}$ 의 기준에 미루어 볼 때 본 연구에서 확인한 HE4 assay의 정밀도는 양호하다고 판 단되었다.

직선성 평가에서 제조사가 제시하는 측정가능범위 내에서 우수한 직선성이 확인되었다. HE4 측정값이 상피성 난소암의 독립적인 예후인자가 될 수 있다는 점을 고려하면, 높은 값까 지 측정가능하고, 비교적 넓은 범위에서 직선성을 보이는 것이 중요하다고 생각된다[24].

CLSI EP17-A2 지침에 따르면 공백검체의 평균 농도와 표 준편차값을 구하여 $\mathrm{LoB}$ 를 설정하도록 제시하고 있다[14]. 그러나 제조사의 측정가능범위의 하한인 $20 \mathrm{pmol} / \mathrm{L}$ 보다 낮 은 값은 $20 \mathrm{pmol} / \mathrm{L}$ 미만 $(<20 \mathrm{pmol} / \mathrm{L})$ 으로 장비의 결과가 표 시되고 있어 $20 \mathrm{pmol} / \mathrm{L}$ 미만에 해당되는 정량값을 얻을 수 없으므로 CLSI 지침에 따라서 $\mathrm{LoB}$ 를 검증할 수 없다. 따라 서 EP17-A2의 대안으로 $0 \mathrm{pmol} / \mathrm{L}$ 농도인 diluent의 RLU 를 20회 측정하고 그 측정치의 평균과 제조사에서 제시하는 0 $\mathrm{pmol} / \mathrm{L}$ calibrator $\mathrm{A}$ 의 허용 RLU 범위를 비교하여 $\mathrm{LoB}$ 를 검
증하였다. 본 연구에서 $\mathrm{LoB}$ 를 정량적으로 검증하지는 못했으 나 제조사가 제시한 RLU 범위 안에 포함되므로 CLIS 지침을 절충하여 평가한 결과라 생각된다. 향후 장비에서 측정 하한보 다 낮은 농도가 '<측정가능농도 하한값 미만'으로 표시되는 검 사법의 경우 검출한계를 정량화된 농도로 평가하는 현재의 지 침에 대한 개선된 지침 마련이 필요할 것으로 생각된다.

최근들어 다양한 검사항목의 측정결과를 조합하여 임상적 인 정보를 제공하는 검사법이 도입되고 있는 실정이며, 2007 년 FDA draft guideline에 따르면 질병의 진단과 치료, 예방 을 위하여 다양한 요소들을 결합하여 단일한, 환자 특이적인 결과, 즉 분류, score, index 등을 산출하는 검사법을 in vitro diagnostic multivariate index assay (IVDMIA)로 정의하고 있다. IVDMIA에 입력되는 값들은 다양할 수 있으며, 각각의 요인들이 임상적인 의미를 가질 수도 있다[25]. 골반종괴의 악 성과 양성 감별진단을 위하여 FDA 첫 승인을 받은 IVDMIA 는 OVA1 (Vermillion Inc., Austin, TX, USA)이다. OVA1 는 영상소견, 폐경 여부와 CA-125 이외 4가지 혈정학적 지 표를 이용하여 index값(0-10)을 계산해주고, 이 값이 높을수 록 악성종양의 가능성을 시사한다[15]. 이와 유사한 맥락에서 $\mathrm{ROMA}$ value는 영상소견을 이용하지는 않지만, 폐경 여부, CA-125와 HE4 결과값을 통하여 난소암의 위험도를 예측하 는 데 이용되고 있다. 폐경 후 여성에서 폐경 전 여성에 비하여 민감도가 높고, OVA1과 비교하여 특이도가 더 높다는 연구들 도 보고되고 있다[26,27]. 본 연구결과 난소암 환자군 중 2 명 에서만 CA-125 수치가 정상범위였으나, HE4 수치는 8명에 서 정상범위에 속하였다. 이들 중 CA-125 수치가 정상범위인 2 명을 제외하고 나머지 6명의 경우는 ROMA value가 25.3\% 의 cutoff보다 컸다. CA-125, HE4 수치와 ROMA value가 정 상을 보였던 2 명의 경우는 검사 당시 수술 후 항암치료를 받 는 중이었으므로 tumor burden이 감소되어 검사결과가 모두 cutoff 이하의 값을 보였을 것이라 판단하였다. 따라서 본 연구 결과는 대상환자군 수가 적은 제한점은 있으나, 골반종괴를 가 진 환자에서 $\mathrm{HE} 4$ 를 단독으로 검사하는 경우 $\mathrm{CA}-125$ 검사보 다 양성예측도가 낮고, ROMA value가 $\mathrm{HE}$ 검사보다 난소암 임상상과의 상관성이 더 우수함을 입증하는 결과라 할 수 있 다.

결론적으로 ARHITECT HE4 assay의 수행능 평가결과 우 수한 정밀도와 측정가능범위의 농도구간에서 직선성을 나타 내었다. 제조사가 제시한 하한 측정범위보다 낮은 검출한계를 보였다. $\mathrm{HE} 4$ 단독검사보다 ROMA value가 골반종괴를 가진 환자의 감별에 도움을 줄 수 있다. 따라서 $\mathrm{HE} 4$ 와 $\mathrm{CA}-125$ 검 사결과를 종합하여 ROMA value를 산출하는 것이 난소암 위 


\title{
Journal of LABORATORY MEDICINE and QUALITY ASSURANCE
}

\author{
Eun-Jung Cho et al • Performance of ARCHITECT HE4 Assay
}

험도를 예측에 임상적으로 유용하게 이용될 것이라 생각된다.

\section{REFERENCES}

1. Jung KW, Won YJ, Kong HJ, Oh CM, Lee DH, Lee JS. Prediction of cancer incidence and mortality in Korea, 2014. Cancer Res Treat 2014;46:124-30.

2. Andersen MR, Goff BA, Lowe KA, Scholler N, Bergan L, Dresher CW, et al. Combining a symptoms index with CA 125 to improve detection of ovarian cancer. Cancer 2008;113:484-9.

3. Ortiz-Munoz B, Aznar-Oroval E, Garcia Garcia A, Covisa Peris A, Perez Ballestero P, Sanchez Yepes M, et al. HE4, Ca125 and ROMA algorithm for differential diagnosis between benign gynaecological diseases and ovarian cancer. Tumour Biol 2014;35:7249-58.

4. Sandri MT, Bottari F, Franchi D, Boveri S, Candiani M, Ronzoni S, et al. Comparison of HE4, CA125 and ROMA algorithm in women with a pelvic mass: correlation with pathological outcome. Gynecol Oncol 2013;128:233-8.

5. Li F, Tie R, Chang K, Wang F, Deng S, Lu W, et al. Does risk for ovarian malignancy algorithm excel human epididymis protein 4 and CA125 in predicting epithelial ovarian cancer: a meta-analysis. BMC Cancer 2012;12: 258.

6. Fuith LC. The distribution of CA125 in the reproductive tract of pregnant and non-pregnant women. $\mathrm{Br} J$ Obstet Gynaecol 1989;96:750.

7. Holcomb K, Vucetic Z, Miller MC, Knapp RC. Human epididymis protein 4 offers superior specificity in the differentiation of benign and malignant adnexal masses in premenopausal women. Am J Obstet Gynecol 2011;205: 358.e1-6.

8. Drapkin R, von Horsten HH, Lin Y, Mok SC, Crum CP, Welch WR, et al. Human epididymis protein 4 (HE4) is a secreted glycoprotein that is overexpressed by serous and endometrioid ovarian carcinomas. Cancer Res 2005;65: 2162-9.

9. Moore RG, Brown AK, Miller MC, Skates S, Allard WJ, Verch T, et al. The use of multiple novel tumor biomarkers for the detection of ovarian carcinoma in patients with a pelvic mass. Gynecol Oncol 2008;108:402-8.
10. Van Gorp T, Veldman J, Van Calster B, Cadron I, Leunen $\mathrm{K}$, Amant F, et al. Subjective assessment by ultrasound is superior to the risk of malignancy index (RMI) or the risk of ovarian malignancy algorithm (ROMA) in discriminating benign from malignant adnexal masses. Eur J Cancer 2012;48:1649-56.

11. Escudero JM, Auge JM, Filella X, Torne A, Pahisa J, Molina R. Comparison of serum human epididymis protein 4 with cancer antigen 125 as a tumor marker in patients with malignant and nonmalignant diseases. Clin Chem 2011;57:1534-44.

12. Clinical and Laboratory Standards Institute. Evaluation of precision performance of quantitative measurement methods: approved guideline. CLSI document EP5-A2. 2nd ed. Wayne (PA): Clinical and Laboratory Standards Institute, 2004.

13. Clinical and Laboratory Standards Institute. Evaluation of the linearity of quantitative measurement procedures: a statistical approach: approved guideline. CLSI document EP6-A. Wayne (PA): Clinical and Laboratory Standards Institute, 2003.

14. Clinical and Laboratory Standards Institute. Evaluation of detection capability for clinical laboratory measurement procedures: approved guideline. CLSI document EP17A2. 2nd ed. Wayne (PA): Clinical and Laboratory Standards Institute, 2012.

15. Simmons AR, Baggerly K, Bast RC Jr. The emerging role of HE4 in the evaluation of epithelial ovarian and endometrial carcinomas. Oncology (Williston Park) 2013;27:548-56.

16. Bast RC Jr, Badgwell D, Lu Z, Marquez R, Rosen D, Liu J, et al. New tumor markers: CA125 and beyond. Int J Gynecol Cancer 2005;15 Suppl 3:274-81.

17. Hellstrom I, Raycraft J, Hayden-Ledbetter M, Ledbetter JA, Schummer M, McIntosh M, et al. The HE4 (WFDC2) protein is a biomarker for ovarian carcinoma. Cancer Res 2003;63:3695-700.

18. Moore RG, Miller MC, Steinhoff MM, Skates SJ, Lu KH, Lambert-Messerlian G, et al. Serum HE4 levels are less frequently elevated than CA125 in women with benign gynecologic disorders. Am J Obstet Gynecol 2012;206:351.e1-8. 


\section{Journal of LABORATORY MEDICINE and QUALITY ASSURANCE \\ Eun-Jung Cho et al • Performance of ARCHITECT HE4 Assay}

19. Farzaneh F, Honarvar Z, Yaraghi M, Yaseri M, Arab $M$, Hosseini $M$, et al. Preoperative evaluation of risk of ovarian malignancy algorithm index in prediction of malignancy of adnexal masses. Iran Red Crescent Med J 2014;16:e17185.

20. Kadija S, Stefanovic A, Jeremic K, Radojevic MM, Nikolic L, Markovic I, et al. The utility of human epididymal protein 4 , cancer antigen 125 , and risk for malignancy algorithm in ovarian cancer and endometriosis. Int J Gynecol Cancer 2012;22:238-44.

21. Sturgeon CM, Hoffman BR, Chan DW, Ch'ng SL, Hammond E, Hayes DF, et al. National Academy of Clinical Biochemistry Laboratory Medicine Practice Guidelines for use of tumor markers in clinical practice: quality requirements. Clin Chem 2008;54:e1-e10.

22. Fraser CG, Hyltoft Petersen P, Libeer JC, Ricos C. Proposals for setting generally applicable quality goals solely based on biology. Ann Clin Biochem 1997;34 ( Pt 1):8-12.

23. Hallamaa M, Huhtinen K, Suvitie P, Perheentupa A. Serum concentrations of HE4 change little during in vitro fertilization. Acta Obstet Gynecol Scand 2014;93:640-6.

24. Kong SY, Han MH, Yoo HJ, Hwang JH, Lim MC, Seo SS, et al. Serum HE4 level is an independent prognostic factor in epithelial ovarian cancer. Ann Surg Oncol 2012; 19:1707-12.

25. US Department of Health and Human Services. Draft guidance for industry, clinical laboratories, and staff: in vitro diagnostic multivariate index assays. http://www. fda.gov/downloads/medicaldevices/deviceregulationandguidance/guidancedocuments/ucm071455.pdf (Accessed Sep 4, 2014).

26. Moore RG, Miller MC, Disilvestro P, Landrum LM, Gajewski W, Ball JJ, et al. Evaluation of the diagnostic accuracy of the risk of ovarian malignancy algorithm in women with a pelvic mass. Obstet Gynecol 2011;118(2 Pt 1):280-8.

27. Jacob F, Meier M, Caduff R, Goldstein D, Pochechueva T, Hacker N, et al. No benefit from combining HE4 and CA125 as ovarian tumor markers in a clinical setting. Gynecol Oncol 2011;121:487-91. 
ARCHITECT HE4 Assay의 수행능 평가 조은정 • 고대현 • 정태동 • 이우창 • 전사일・민원기

울산대학교 의과대학 서울아산병원 진단검사의학과

배경: 난소암에서 과발현되는 인간부고환단백 4 (human epididymis-specific protein 4, HE4)는 상피성난소암의 중요한 종양표지자로 알려져 왔다. 그리고 $\mathrm{HE} 4$ 는 양성과 악성의 골반종괴를 감별하 는 데 있어서 cancer antigen 125 (CA-125)보다 높은 진단적 특이도를 보인다. HE4와 CA-125 결과를 종합하여 산출하는 Risk of Ovarian Malignancy Algorithm (ROMA) value는 난소암의 위 험도 산출에 이용될 수 있다. 본 연구에서는 ARCHITECT HE4 assay (Abbott Laboratories, USA) 와 ROMA value의 수행능을 평가하고자 하였다.

방법: Clinical and Laboratory Standards Institute의 지침에 근거하여 정밀도, 직선성, 검출한계를 평 가하였다. 모든 검사는 ARCHITECT i2000 immunoassay analyzer (Abbott Laboratories, USA) 장비로 ARCHITECT HE4 assay 시약을 사용하여 측정하였다. ARCHITECT HE4 정도관리물질, calibrator B (30 pmol/L), calibrator F (1,500 pmol/L), multi assay diluent $(0.0 \mathrm{pmol} / \mathrm{L})$ 와 잔여 혈 청검체를 이용하였다. 환자군과 대조군에서 폐경 유무에 따라 ROMA value (\%)를 계산하였다.

결과: 정밀도 평가결과 모든 농도에서의 총 변이계수는 모두 $3 \%$ 미만이었고, 제조사의 측정가능범위 안의 농도구간에서 직선성을 만족하였다. 검출한계는 제조사가 제시한 측정범위 하한보다 낮았다. 난 소암 환자군에서의 ROMA value값은 건강한 대조군과 비교하여 매우 높게 관찰되었다.

결론: ARCHITECT HE4 assay의 수행능 평가결과 정밀도, 직선성이 우수하였으며, HE4검사는 ROMA value와 함께 골반종괴가 있는 환자에서 난소암의 조기진단과 위험도 평가에 유용하게 사용 될 수 있을 것으로 생각된다.

(J Lab Med Qual Assur 2014;36:149-156)

교신저자: 이우창

우) 138-736 서울시 송파구 올림픽로 43길 88, 울산대학교 의과대학 서울아산병원 진단검사의학과

Tel: 02) 3010-4506, Fax: 02) 478-0884, E-mail: wlee1@amc.seoul.kr 